\title{
FACTORS THAT AFFECTED COLLABORATIVE GOVERNANCE IN SPATIAL PLANNING OF DEPOK CITY
}

\author{
DAVID SAPUTRA ${ }^{1}$, IRFAN RIDWAN MAKSUM ${ }^{2}$ \\ Major of Public Administrative Sciences, STISIP Imam Bonjol ${ }^{1}$, Faculty of Administrative \\ Sciences, University of Indonesia ${ }^{2}$ \\ davidsaputrajbk@gmail.com ${ }^{1}$, irm01@yahoo.com²
}

\begin{abstract}
Abstrak: Penelitian ini bertujuan untuk menganalisis faktor-faktor yang mempengaruhi tata kelola kolaboratif dan juga upaya membangun tata kelola kolaboratif dalam penataan ruang di kota Depok. Penelitian ini menggunakan metode kualitatif dengan pendekatan postpositivis. Metode pengumpulan data terdiri dari (1) Data primer yang dikumpulkan melalui wawancara mendalam dengan Dinas Pekerjaan Umum dan Penataan Ruang Kota Depok; Badan Perencanaan Pembangunan Kota Depok; dan pemangku kepentingan di Depok terkait dengan masalah penelitian seperti pengembang perumahan dan sosial masyarakat. (2) Data sekunder dikumpulkan melalui studi pustaka dan dokumentasi pada Dinas Pekerjaan Umum dan Penataan Ruang Kota Depok. Menurut peraturan perundang-undangan Indonesia Pasal 26 Tahun 2007 tentang Penataan Ruang, setiap kota di Indonesia wajib memiliki Ruang Terbuka Hijau (RTH) minimal 30 persen dari luas wilayahnya. Hal ini juga bertujuan untuk meningkatkan kerjasama semua elemen dalam penataan ruang kota Depok. Hasil penelitian ini menunjukkan bahwa implementasi tata kelola kolaboratif dalam penataan ruang kota Depok belum efektif karena Depok hanya memiliki RTH 3.227,26 ha kurang dari 30 persen dari luas kota 202,9 KMㄹ ; pemusatan ekonomi di satu wilayah tertentu seharusnya ditujukan untuk layanan perkantoran atau kota; dan peran pemerintah masih dominan dalam kerjasama dengan pemangku kepentingan dalam penataan dan pengelolaan tata ruang melalui diskusi publik, dengar pendapat, dan konsultasi publik. Kondisi tersebut dipengaruhi oleh beberapa faktor: kurangnya struktur jaringan; kurangnya akuntabilitas/tanggung jawab distributif; dan kurangnya kepercayaan antar peserta dalam penataan ruang kota Depok.
\end{abstract}

Kata Kunci: Collaborative Governance, Good Governance, Penataan Ruang, Ruang Terbuka Hijau.

\begin{abstract}
The aims of the study are to analyse the factors that affected collaborative governance and also efforts to build collaborative governance in spatial planning in the city of Depok. This research used qualitative method with post-positivist approach. The data collection method consists of (1) Primary data which were collected through in-depth interviews with Public Works and Spatial Planning Department of Depok city; Development Planning Board of Depok city; and stakeholders in Depok related to the research problem such as housing developers and social society. (2) Secondary data were collected through the literature and documentation at the Public Works and Spatial Planning Department in Depok city. According to Indonesian laws and regulations Article 26 of 2007 on Spatial Planning, each city in Indonesia is required to have a Green Open Space (GOS) of at least 30 percent of its territory. It is also purposed to increase cooperation of all elements for Depok's spatial planning. This research indicates that the implementation of collaborative governance in Depok's spatial planning has not been effective because Depok only has 3227.26 ha GOS less than 30 percent of $202.9 \mathrm{KM}^{2}$ city wide; the economic centralization in one particular region should have been intended for office or municipal services; and the role of government is still dominant in cooperation with stakeholders in spatial planning and management through public discussion, public hearing, and public consultation. Such a condition is influenced by several factors: lack of networked structure; lack of distributive accountability/ responsibility; and the lack of trust among the participants in spatial planning of Depok city.
\end{abstract}

Keywords: collaborative Governance, Good Governance, Spatial Planning, Green Open Space. 


\section{A. Introduction}

Spatial planning includes the planning, utilization and control of space utilization (UU No. 26 Year 2007 on Spatial Planning). Spatial planning is the starting point for achieving sustainable spatial success which directly affects the utilization and control of space utilization. Spatial planning is a plan of space utilization that is designed to maintain harmony of intersectoral development in the framework of development of long-term development programs (Nurmandi, 1999). Therefore, the spatial arrangement is crucial to be managed and integrated well for the sustainable development for the future generation.

However, the spatial arrangement implemented in Indonesia has not been well managed and not well integrated with the stakeholders yet. It is also still far from public expectation. Various natural disasters occurred in Indonesia such as floods, landslides, and so forth might be an obvious indication of the impact of mismanagement of spatial planning.

Some argues that such a mismanagement is caused by the personal interest of certain groups which has definitely hindered the national development aspired in Indonesia. In connection with that, the head of the center for data and public relations of Badan Nasional Penanggulangan Bencana (The National Agency for Disaster Countermeasure), Sutopo Purwo Nugroho, stated that the extent of flood and landslide disaster in Indonesia shows that development trend has not been well integrated yet as this kind of disaster is more caused by human factor rather than nature (Kompas.com, 2017).

In ordert to overcome the aforementioned issues, the government in West Java Province has put its spatial planning policy into Rencana Pembangunan Jangka Menengah Daerah (RPJMD) that is Regional Mid-Term Development Plan for the year 2013-2018. This policy is also supported by West Java Regional Regulation No. 22 of 2010 on the Spatial Plan of West Java Province Year 2009-2029, where this policy is directed to create equitable development of planned areas and integrated with all sectors as stated in a spatial plan. This spatial plan, then, is used as a reference of spatial policy for development in each sector so that space utilization in every city can be synergistic, harmonious and sustainable.

Nonetheless, the reality is different, as stated by Wahana Lingkungan Hidup Indonesia of West Java or WALHI (Indonesian Forum for Environment), the spatial policy in West Java including Depok City has not run properly due to the still occurrence of environmental damage as a result of land conversion which significantly increaseand over the last few years, and it is also caused by spatial utilization outside the public interest such as for industrial development, settlement, mining and so on.

This condition can be seen in Figure 1 where the high increase of functional shift of land during five consecutive years from 2010 to 2014 in West Java Province. While the land previously used for community needs such as agriculture, protected forest and green open space, it had been now converted into the interests of a group of people without considering the role of other stakeholders in urban development in West Java.

Figure 1: Over land function in West Java period 2010-2014

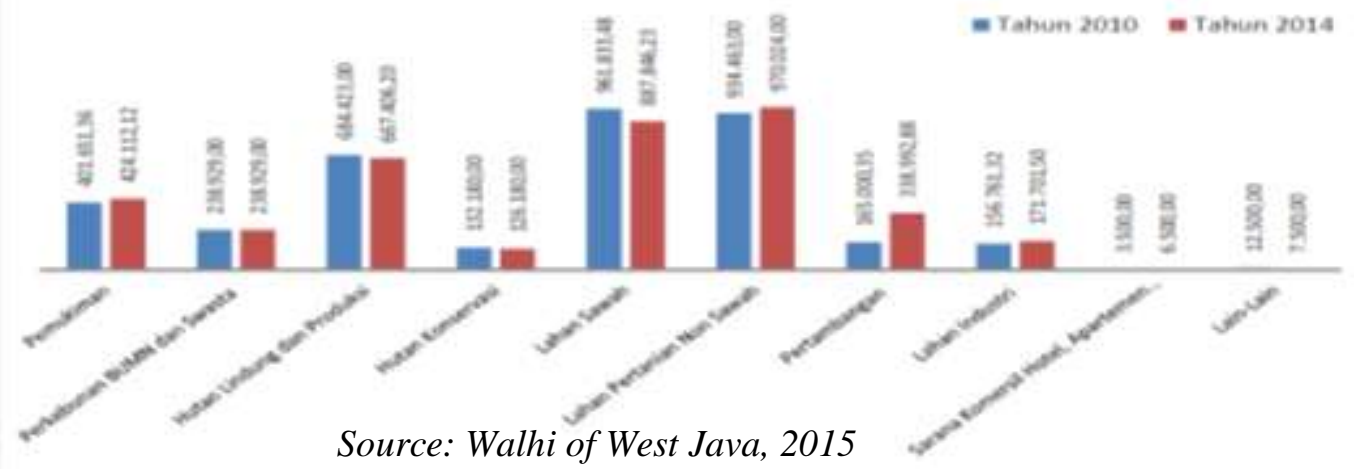


Based on the bar chart presented above, the most significant land conversion is the decrease of paddy fields each year which reaches 14,800 hectares. In 2010, the area of the field was 961.883 hectares, whereas in 2014 it decreased significantly about 74,037 hectares to 887,846 hectares. As urged by Dadan Ramdan, the director of WALHI of West Java, the conversion of forest area is no different from previous years like 2010 to 2014, dominated by diversion into the mining sector, infrastructure development, toll roads and roads. The area of forest which has been converted until 2015 reaches 28,900 hectares, which is dominated by mining land (Tempo.com, 2015).

Similarly, in Depok city, data from the official website of the city of Depok indicates that while in 2010 farmland and plantation initially ranged 589 hectares, it has then decreased every year until 2014 to only 164 hectares. These functional shifts of agricultural lands and plantations functional are the result of Industrial growth. In other words, the convert of land is intended for industrial sector, mining and settlement needs. Besides that, other commercial condominium facilities have also contributed in reducing the productive agricultural land and other non-agricultural land. This condition has a direct impact on locals who have lost their land because of the displacement of their fields, so that food production decreases considerably from year to year.

Therefore, the arrangement of urban space becomes an important issue in development, which in its arrangement demands the role of government institutions that can accommodate all interests within the framework of democracy through cooperation among stakeholders as an effort and response of the government in handling public problems, called Collaborative Governance. Ansell and Gash described a new strategy of government called collaborative governance. This kind of governance involves various stakeholders to work collaboratively with the government apparatus to make joint decisions (Ansell and Gash, 2007: 543). More specifically, Ansell explained that collaborative governance is a governance arrangement whereby one or more public institutions directly engage non-government stakeholders in a collective, consensus-oriented, deliberative collective decision-making process aimed at creating and implementing public policies and managing programs or public assets (Ansell and Gash, 2007: 544).

This notion is in line with those disclosed by Donahue and Zeckhauser (2011: 4) that every level of government agency has the opportunity to collaborate with private parties in achieving public goals more effectively than done by the government itself. More precisely, Donahue and Zeckhauser (2011:30) interpret that "collaborative governance can be thought of as a form of agency relationship between government as principal, and private players as agents". This collaborative governance, therefore, can be regarded as a form of cooperative relationship between government as regulator and private parties as executors. In Depok City spatial arrangement, Collaborative Governance might be considered very necessary because it can not be denied that every stakeholder in Depok City has limited capacity in fulfilling their own needs, so that they will exchange mutual resources with each other that is symbiotic mutualism, sharing for complementary purposes. Through this collaboration, all parties including the community will have a sense of ownership and responsibility to achieve the goals so as to increase opportunities in the development and success of sustainable development.

Spatial arrangement in Depok City has not been managed collaboratively, due to various issues. As proposed by M. Rahmat Yananda (2018), an expert in urban administration and the Director of Makna Informasi Indonesia, the spatial arrangement in Depok City and other cities still have masterplan which is hierarchical, where the municipal government only follows what has been set by the central government and has no authority in organizing or planning but adapting to their respective regions. Similir to the national RTRW which is relegated to the regions to be translated into provincial and district/city RTRWs. this demonstrates a hierarchical masterplan which indicates the lack of collaboration between central and local governments. 


\section{B. Research Methodology}

This research used qualitative method with post-positivist approach. Used the theory as basic to analyse reality in the society, that is for intrepretation of development in making decision. This research used the data collection method consists of: Primary and Secondary data. Primary data, were collected through in-depth interviews with Public Works and Spatial Planning Department of Depok city; Development Planning Board, and the developer of housing of Depok city; and also stakeholders in Depok related to the research problem such as housing developers and social society. Secondary data, were collected through the literature and documentation at the Public Works and Spatial Planning Department in Depok city. The aims of the research are to analyse the factors that affected collaborative governance and also efforts to build collaborative governance in spatial planning in the city of Depok. Data analyse methode in this research are to presented of field data, researched, and then analysis by logic, and to describe of research object and conclucion. Operational concepts in this research are collaborative governance in spatial planning of the city, the concepts theorys by Ansell and Gash (2007) and then Mulyandari (2011).

\section{Result and Discussion}

Referring to the factors that can determine the model of collaborative governance in the spatial arrangement by Ansell and Gash (2007), where these variables form a contingency model of collaborative governance as shown in more detail in the following figure:

\section{Figure 2: Collaborative Governance Model}

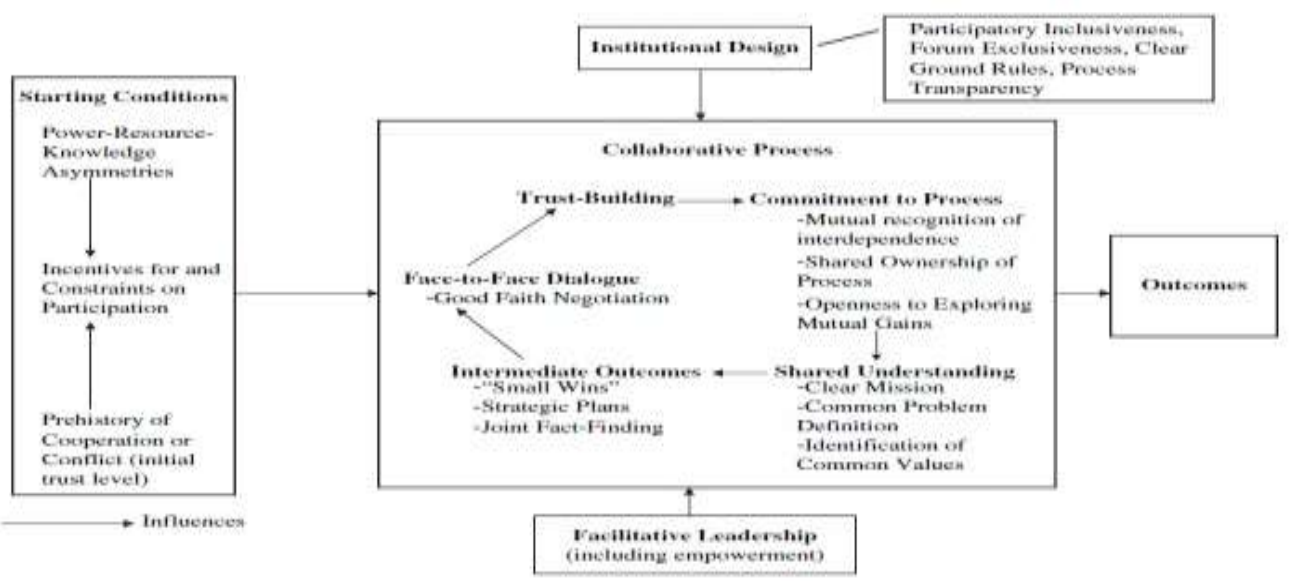

Source: Ansell dan Gash (2007: 8)

From the picture above, it can be seen that each of these variables can be sorted into smaller variables. It shows that the determinants of collaborative governance in Depok City was not effective, because there was still hierarchy from the central government. So in a collaborative government, the local government does not feel the equal rights, obligations, responsibilities, authority, and opportunities for accessibility in preparing or planning RT\&RW (the neighborhood and hamlet). So the local government will only run the RT\&RW (the neighborhood and hamlet) according to the guidelines without considering the complaints or aspirations of the stakeholders in Depok City.Some efforts had been made to capture the aspirations of stakeholders by Depok City Government in public discussion, public hearing, and consultation public. Those aimed to find out what and how exactly the level of understanding, response, and public expectations of the layout of the city of Depok at this time and that will be planned in the future. As if the activity was a mere formality but at the end it was back to the national spatial reference.

This had an impact on the spatial arrangement of Depok City, is seen in the case of congestion that increasingly haunted the city of Depok lately which was caused by the high traffic flow. Every traffic jam in Depok City is always followed up with partial handling and 
always rely on resetting the traffic cycles, such as building separators, and this was not a comprehensive policy (Titro.id, 2018). The government built a road separator that makes Margonda streets divided into slow lanes and smooth lanes. However, these road separators did not reduce the congestion that occurred. Today, Margonda street becomes the center of the worst congestion in the city of Depok. That means that in building the highway, the government did not consider the complaints of stakeholders, the problems that occur in the field, or how the participation of people affected directly from the bottleneck is. Here, the concept to increase the cooperation and roles division for spatial management [according to Regional Regulation of Kota Depok No. 1 Year 2015 on RT RW (the neighborhood and hamlet)] had not been implemented maximally.

The road separator policy is built by not including the participation of the stakeholders of the community, NGOs, academics, and even capital owners to carry out the division of responsibilities in overcoming the congestion. If communities or NGOs submit their complaints on the road usage issues, thus academics can analyze the objectives and impacts of the policies before they are implemented, while the capital owners can facilitate funds if governments lack to create vital spaces in an effort to cope with congestion. In other cases, the problem of the uncontrolled of land conversion led to insufficient of the green open space (GOS) in Depok city from year to year, which actually should cover 30 percent of Depok City area of 202.9 $\mathrm{KM}^{2}$. It means that Depok City should have GOS area of 6,087 ha, however, until now it only has a total green space of 3,271.26 ha (according to the Data of Dept. of PUPR Depok City, 2018). From the data shows automatically until now GOS Depok city has not been fulfilled even still far below target.

This was due to the addition of new settlements or business premises that were not well organized. As stated by the Head of Sub Division of Residential Infrastructure and Natural Resources Depok City (2018) that the 30 percent of deficit GOS in Depok City was constrained by the lack of public participation to understand the importance of green space for everyone. In private execution, it was very difficult to apply and take a long time to create or improve the green space despite socializations had shared to the community. The problem above happened because people were less confident about the actions or services that were provided by the government about the open space. People preferred to own the land and sell it to a housing developer rather than given to the government for public land. Here, "trustbuilding" within the stakeholders or communities and governments was less established, they lack the confidence that the government can be given the confidence to cultivate private land into green space as a form of mutual interest. In this case, every stakeholder should trust each other because as a manifestation of professional relationships were established to achieve successful implementation of collaborative governance.

If the lack of green open space continues it will cause floods, landslides, and other disasters because the water absorptions are diminished and the function of forest or trees as a retaining rain were logged for housing. It was seen that flood and landslide disaster in Depok city was quite high in 2017 where there were 5,071 casualties suffered and displaced due to frequent floods. Then there was 1 person died and 1 person was injured due to landslide (Data processed from Data Indonesia Disaster Information, BNPB Indonesia, 2017). Then the issue of centralization of economic infrastructure in the Margonda area should be preferred for office or city services (based on Public Works and Human Settlements Service Data of 2018 on General Provisions of Depok City Zoning Regulation), but Margonda was also maintained as an economic center as stated in the draft Indication of Development Program Depok City. So the existence of supermarkets to settlements that were increasingly growing without considering the distance between one supermarket to another according to the needs of the community.

The fact that was found in Margonda that there were at least 5 adjacent supermarkets and housing in the building process, thus makes Margonda area as the centric. This happens because the entrepreneurs or private parties believe that only the Margonda area that can be used as an economic area, and there was no potential for other regions (according to the 
interview with Head of Dept. of Infrastructure of Residential and Natural Resources Depok, 2018). All in all, making Margonda street as the center area, the government or stakeholders did not believe in the potential of other regions to grow and sustain the economy of Depok City.

\section{Conclusions}

The determinants all factors of collaborative governance in Depok City was not effective, because there was still hierarchy from the central government. So in a collaborative government, the local government does not feel the equal rights, obligations, responsibilities, authority, and opportunities for accessibility in preparing or planning RT\&RW (the neighborhood and hamlet). The government built a road separator did not reduce the congestion that occurred. The road separator policy is built by not including the participation of the stakeholders of the community, NGOs, academics, and even capital owners to carry out the division of responsibilities in overcoming the congestion. Face to face dialogue was not built here. As if the activity was a mere formality but at the end it was back to the national spatial reference. GOS Depok city has not been fulfilled even still far below target, we can see from uncontrolled of land conversion led to insufficient of the green open space (GOS) in Depok city from year to year, which actually should cover 30 percent of Depok City area of $202.9 \mathrm{KM}^{2}$. If the lack of green open space continues it will cause floods, landslides, and other disasters because the water absorptions are diminished and the function of forest or trees as a retaining rain were logged for housing. Here "trust-building" within the stakeholders or communities and governments was less established, they lack the confidence that the government can be given the confidence to cultivate private land into green space as a form of mutual interest. Then, the last factor is the people were less confident about the actions or services that were provided by the government about the open space. People preferred to own the land and sell it to a housing developer rather than given to the government for public land.

\section{References}

Ansell, Chris and Alison Gash. 2007. Collaborative Governance in Theory and Practice, Journal of Public Administration Research and Theory. Published by Oxford.

Yananda, Muhammad Rahmat, Irfan Ridwan Maksum dan Heri Fathurahman. 2017. Promoting Collaboration in Jabodetabekjur: A Learning Regions Perspective on Knowledge-Based Economy. Journal of Policy and Governance Review, Vol. 1, Issue 1, Januari 2017

Scharpf, F.W. 1978. Interorganizational Policy Studies: Issues, Concepts and Perspectives. in: K.I. Hanf and F.W. Scharpf (eds). 1978. Interorganizational Policy Making: Limits to Coordination and Central Control. London: Sage: 345-370.

Donahue, Jhon and Richard, Zeckhauser. 2011. Collaborative Governance: Private Roles for Public Goals in Turbulent Times. New Jersey: Princeton University Press

Cahyadi, Arif. 2016. Penerapan Good Governance dalam Pelayanan Publik. Jurnal Penelitian Administrasi Publik, Vol. 2 No. 2, hal. 479 - 494, Oktober 2016

Suweda, I Wayan. 2011. Penataan Ruang Perkotaan yang Berkelanjutan, Berdaya Saing dan Berotonomi. Jurnal Ilmiah Teknik Sipil, Vol. 15, No. 2, Juli 2011

Dwiyanto, Agus (Editor). 2006. Mewujudkan Good Governance Melalui Pelayanan Publik. Yogyakarta: UGM Press

United Nations Development Programme. 1997. Governance for Sustainable Human Development. New York: UNDP

Lembaga Administrasi Negara dan Badan Pengawasan Keuangan dan Pembangunan. 2000. Akuntabilitas dan Good Governance. Jakarta: Lembaga Administrasi Negara dan Badan Pengawasan Keuangan dan Pembangunan

Hetifah Sj. Sumarto. 2003. Inovasi, Partisipasi dan Good Governance. Jakarta: Yayasan Obor Indonesia

$\begin{array}{lll}436 & \text { Lembaga Penelitian dan Penerbitan Hasil Penelitian Ensiklopedia } & \text { E-ISSN: 2657-0300 } \\ & \text { P-ISSN: 2657-0319 }\end{array}$


Budihardjo, Eko. 2005. Tata Ruang Perkotaan. Bandung: PT. Alumni Santoso, Jo. 2006. (Menyiasati) Kota tanpa Warga. Jakarta: Centropolis

Soerjani, Moh et al. 1987. Lingkungan: Sumber Daya Alam dan Kependudukan dalam Pembangunan. Jakarta: UI-Press

Nurmandi, Achmad. 1999. Manajemen Perkotaan: Aktor, Organisasi dan Pengelolaan Daerah Perkotaan di Indonesia. Yogyakarta: Lingkaran Bangsa

Supriyatno, B. 2009. Manajemen Tata Ruang. Tangerang: CV. Media Berlian

Goldsmith, S and Donald F. K. 2009. Unlocking The Power Of Networks: Keys To High Performance Government. Wachington, D.C: Brookings Institution Press

Ganie-Rochman, Meuthia. 2000. Artikel "Good Governance : Prinsip, Komponen dan Penerapannya" dalam HAM: Penyelenggaraan Negara Yang Baik dan Masyarakat Warga. Jakarta: Komnas HAM

Sedarmayanti. 2007. Sumber Daya Manusia Dan Produktivitas Kerja. Bandung: Mandar Maju

Sedarmayanti. 2009. Manajemen Sumber Daya Manusia, Reformasi Birokrasi, dan Manajemen Pegawai Negeri Sipil. Bandung: Refika Aditama

O'Flynn, J and John W. 2008. Collaborative Governance: A New Era Of Public Policy In Australia. Australia: E Press

Afful-Koomson, T and Kwabena O.A. 2013. Collaborative Governance in Extractive Industries in Africa. Africa: Pixedit Limited

Ratner. 2012. Collaborative Governance Assessment. Malaysia: CGIAR

Akib, Muhammad, Charles Jackson dkk. 2013. Hukum Penataan Ruang. Bandar Lampung: PKKPUU FH UNILA

Mulyandari, Hestin. 2011. Pengantar Arsitektur Kota. Yogyakarta: ANDI Yogyakarta

Pittas, M, and Ferebee, A (editors). 1982. Education for Urban Design. New York: Institute for Urban Design

Wanna, John. 2009. Policy in Action. Sydney: UNSW Press

Wahab, Solichin Abdul. 2002. Analisis Kebijakan Negara. Jakarta: Rieneka Cipta

Rhoddes, R.A.W. 1997. Understanding Governance Policy: Network, Governance, Reflexivity, and Accountability. Buckingham, Philadelpia: Open University Press

Pierre, Jon, and B. Guy Peters. 2000. Governance, Politics and the State. London: MacMillan Press Ltd

Ahmadi, Wiratni. 1995. Pengaturan Tata Ruang Yang Berwawasan Lingkungan Hidup. Bandung. Makalah Disampaikan Dalam Seminar Sehari Lingkungan Hidup Dan Tata Ruang

Bungin, Burhan. 2007. Penelitian Kualitatif. Surabaya: Kencana

Abidin Kusno. 2006. Ruang, Kekuasaan dan Identitas Dalam Konteks Urban di Indonesia: Pendekatan Historikal. Dalam Berita LBH Jakarta, Nomor: 11 / Oktober / 2006

Slamet Darwani. 2007. Sekretariat WALHI Jakarta-Pejaten. Rumah Apresiasi. htm: 21 November 2007

Nurkholis Hidayat. 2007. Sekretariat LBH Jakarta-Jl. Diponegoro. Rumah Apresiasi. htm: 21 November 2007

Morse, Ricardo S, and John B. Stephens. 2012. Teaching Collaborative Governance: Phases, Competencies, and Case-Based Learning. Journal of Public Affairs Education, Vol. 18, No. 3, pp. 565-583, Summer 2012

Hidayat, Sri. 2017. Pelibatan Publik Dalam Perspektif Perencanaan Ruang yang Partisipatif dan Kolaboratif.

Blair, Neale, James Berry and Stanley McGreal. 2005. Regional Spatial Policy for Economic Growth: Lessons from the Deployment of Collaborative Planning in Northern Ireland. Journal of Urban Studies, Vol. 44, No. 3, 439-455, March 2007

Utoyo, Bambang. 2010. Governance dan Penataan Ruang (Studi Model Perencanaan Tata Ruang Kota Melalui Penerapan Metode Analytical Hirarchy Process 